Japan. J. Med. Sci. Biol., 19, 229-238, 1966

\title{
GROWTH ACCELERATION OF A MOUSE CELL LINE AFTER INFECTION WITH FRIEND LEUKEMIA VIRUS
}

\author{
HIROSHI YOSHIKURA, YASUKO HIROKAWA \\ AND MASA-ATSU YAMADA \\ Department of Pathology, National Institute of Health, Tokyo
}

(Received: September 5th, 1966)

MLg cell line, originated from the lungs of newborn ddY mice, was infected with Friend murine leukemia virus. The infected cells were found to be increased in the growth potential while producing the virus. The increase in the growth potential was possibly mediated by some heat stable growth enhancing substance (s).

\section{INTRODUCTION}

During the past ten years, cell transformation in vitro with murine leukemia viruses has been a subject of interest for numerous investigators. Although propagation of murine leukemia viruses in tissue culture was successfully demonstrated by several investigators (Chamorro et al., 1962 ; Ginsberg and Sachs, 1961 ; Manaker et al., 1960 and 1964; Moore and Friend, 1958 ; Moore, 1963; Osato et al., 1964; Peries et al., 1964 ; Sinkovics and Howe, 1964 ; Wright and Lasfargues, 1965), observations of the cellular changes specifically induced with murine leukemia viruses have been scanty except for the recent work by Osato et al. (1966).

We preliminarily reported the growth acceleration of a mouse cell strain after treatment with homogenate of the Friend leukemia virus-infected spleens (Yoshikura et al., 1965). In the report, virus assay was not performed and it was uncertain whether the phenomena were due to the virus infection or not. Our recent experiments confirmed the previous results and further demonstrated that the cells treated with homogenate of the Friend leukemia virus-infected spleens continued to produce virus. These informations are detailed in this report.

\section{MATERIALS AND MeTHODS}

Virus: The virus was obtained from Dr. Oboshi, National Cancer Center, Tokyo, and from Dr. Odaka, Institute for Infectious Diseases, the University of Tokyo. The virus obtained from Dr. Oboshi was a ddN mouse passage line and that obtained from Dr. Odaka was a DDD mouse passage line. We maintained the two virus strains as ddY mouse passage lines.

For experiments, we used the markedly enlarged spleens from the mice inoculated 10 to 14 days previously. The spleens were homogenized with a blendor by adding 9 volumes of phosphate-buffered saline. Supernatant of the homogenate centrifuged at 3,000

吉倉 広・広川 康子・山田 正篤（国立予防衛生研究所病理部） 
rpm for $30 \mathrm{~min}$ was used as the inoculum. Virus titration was performed by injecting serial ten-fold dilutions intraperitoneally into 3 to 5 week-old ddY mice in a dose of $0.25 \mathrm{ml}$. The spleens weighing $0.5 \mathrm{~g}$ or more on the $21 \mathrm{st}$ day or later after injection were judged as an indication of infection.

Mice: Random bred ddY mice were used.

Medium: All experiments were carried out in Eagle's minimal essential medium (MEM) supplemented with calf serum and tryptose phosphate broth, both at a concentration of $10 \%$. To maintain the noninfected MLg cells or infected MLg cells, streptomycin and penicillin were added to the culture medium at a concentration of $100 \mu \mathrm{g} / \mathrm{ml}$ and 100 units $/ \mathrm{ml}$, respectively. The concentration of bicarbonate was $1.0 \mathrm{mg} / \mathrm{ml}$.

Establishment of MLg cell line: In January, 1964, the lungs were removed aseptically from a litter of normal newborn ddY mice and minced with scissors. The finely minced tissue was washed once with phosphate-buffered saline to remove blood cells and seeded into a bottle containing MEM supplemented with $10 \%$ calf serum. One week later, tissue fragments were removed. The migrated cells adherent to the glass surface were trypsinized with $0.25 \%$ trypsin and cultured in MEM containing $20 \%$ calf serum. After subcultured 3 times, the cells ceased to grow well. The cell culture was left for a month without subculture. After subcultured once, the cell culture was left for further 3 weeks without subculture. Towards the end of March, the cellular growth became active. The cells were subcultured thereafter when they became confluent. In May, 1965, the culture medium was changed to MEM with calf serum and tryptose phosphate broth, both at a concentration of $10 \%$.

The cells at different passages were frozen with a medium consisting of 7 parts MEM, 2 parts calf serum and one part dimethyl sulfoxide and stored at $-70^{\circ} \mathrm{C}$ until use.

The experiments were carried out with the cells at the 40 th to 70 th passages, i. e. 350 to 500 days in vitro.

Infection of MLg cells with the Friend leukemia virus: The cells were infected with the virus in a humidified incubator flushed with $\mathrm{CO}_{2}$. $5 \times 10^{5}$ cells were seeded into each $60-\mathrm{mm}$ petri dish containing $5 \mathrm{ml}$ of culture medium. After incubated overnight, the cultures were inoculated with varying amounts of homogenate of the Friend virusinfected spleens (HFV), further incubated overnight and the culture medium was changed.

Estimation of the density of the cell population: The areas where the cells had grown were traced onto a sheet of co-ordinate paper before trypsinization and the size of the areas was estimated by counting the number of sections of $1 \mathrm{sq} . \mathrm{mm}$. The cells were trypsinized with $0.5 \mathrm{ml}$ of 0.05 per cent trypsin at $37^{\circ} \mathrm{C}$ for $5 \mathrm{~min}$. Trypsin action was stopped by diluting with $4.5 \mathrm{ml}$ of culture medium. After brief agitation to disperse the cell clumps, the cell number was estimated from hemocytometer counts. Dividing the total number of the cells in a petri dish by the size of the area where the cells had grown gave the density of the cell population (cells/sq. $\mathrm{cm}$ ).

The cell suspension thus obtained was used for plating and for growth estimation.

Procedures of cell plating: The suspension was diluted in culture medium to a concentration of $10^{4}$ or $10^{5} \mathrm{cell} / \mathrm{s} / \mathrm{ml}$. One-tenth $\mathrm{ml}$ of each dilution was transferred to a $60-\mathrm{mm}$ petri dish containing $5.0 \mathrm{ml}$ of culture medium and the cultures were incubated in a $\mathrm{CO}_{2}$ cabinet.

Procedures of cell growth estimation: The cell suspension was adjusted to a desired concentration and distributed into tubes in the amount of $1.5 \mathrm{ml}$. The cells were counted every day or every other day by the method of enumeration of isolated cell nuclei (Takano et al., 1956). 


\section{RESULTS}

\section{Growth Characteristics of the Cells Treated with HFV}

The monolayer cultures of MLg cells were treated with varying amounts of HFV. When a culture was inoculated with 0.4 or $0.5 \mathrm{ml}$ of $\mathrm{HFV}$, we found within 3 or 4 days after inoculation sharply outlined focal areas where the cell population was unusually large and the cells proliferated in a multilayer. Such cells tended to be fibroblast-like and superimposed, although the normal cells were polygonal and flat in appearance and proliferated in a monolayer. The cells in the other part of the culture were dead. When the dose of the inoculum was $0.2 \mathrm{ml}$ or less, the cultures remained apparently normal.

Four-tenths or $0.5 \mathrm{ml}$ of homogenate of the noninfected spleens (HNS) induced no apparent cellular changes; but the same amount of the mixed homoganate of the noninfected spleens and livers (HNSL) induced cell death in some part of the cultures. The surviving cells, however, grew not in a multilayer but in a monolayer. The density of the cell population was estimated 7 days after the inoculation. The density of the culture treated with $0.4 \mathrm{ml}$ of $\mathrm{HFV}$ was ten times as high as that of the culture treated with the same amount of HNSL (Table 1).

$\mathrm{HFV}$ was inactivated by heating at $56^{\circ} \mathrm{C}$ for $30 \mathrm{~min}$. and then centrifuged at 3,000 rpm for $30 \mathrm{~min}$. Clear supernatant (iHFV) was obtained. Inoculation of 0.4 or $0.5 \mathrm{ml}$ of iHFV induced such cellular changes that were the same, macroscopically and microscopically, as induced by the same amount of HFV. The surviving cells proliferated in a multilayer. The density of the cell population was as high as that of the culture treated with the same amount of HFV (Table 2).

In order to know whether the treatment with HFV or iHFV actually increased the growth potential of the cells, plating and growth estimation were performed at the sub-

Table 1. The population density of the cell culture treated with HFV and those treated with HNSL

\begin{tabular}{lccc}
\hline Treatment with & $\begin{array}{c}\text { No. of cells } \\
\text { per dish } \\
\left(\times 10^{6}\right)\end{array}$ & $\begin{array}{c}\text { Area where cells } \\
\text { had grown } \\
(\mathrm{sq} . \mathrm{cm})\end{array}$ & $\begin{array}{c}\text { Dedsity of cell } \\
\text { population } \\
\left(\times 10^{5} \text { cells/sq. cm }\right)\end{array}$ \\
\hline $0.40 \mathrm{ml}$ of HNSL & 1.5 & 10.2 & 1.5 \\
$0.40 \mathrm{ml}$ of HFV & 2.1 & 1.4 & 15.3 \\
\hline
\end{tabular}

The virus was obtained from Dr. Oboshi.

Table 2. The population density of the cell cultures treated with HFV or heat-inactivated HFV (iHFV). The virus was obtained from Dr. Odaka

\begin{tabular}{cccc}
\hline Treatment with & $\begin{array}{c}\text { No. of cells } \\
\text { per dish } \\
\left(\times 10^{5} \text { cells }\right)\end{array}$ & $\begin{array}{c}\text { Area where cells } \\
\text { hed grown } \\
(\text { sq. cm })\end{array}$ & $\begin{array}{c}\text { Density of cell } \\
\text { population } \\
\left(\times 10^{4} \text { cells/sq. cm }\right)\end{array}$ \\
\hline untreated & 20 & $24.6^{*}$ & 8 \\
$0.04 \mathrm{ml} \mathrm{HFV}$ & 22 & $24.6^{*}$ & 9 \\
$0.40 \mathrm{ml}$ HFV & 7.8 & 2.6 & 30 \\
$0.40 \mathrm{ml}$ of i-HFV & 8.2 & 3.2 & 26 \\
\hline
\end{tabular}

* no dead area. 
culture of the cells. Four petri dishes were prepared for each group; two were seeded with $10^{3}$ cells and the other two with $10^{4}$ cells per dish. After 7 days, the cultures were fixed with methanol and stained with crystal violet. The number of dense and large colonies produced by the cells treated with HFV was much larger than that produced by the cells untreated or treated with iHFV or HNSL (Table 3). In many experiments, however, there appeared colonies of intermediate types between dense large colonies and sparse small colonies; hence, we counted, as a matter of convenience, colonies which were larger than $1.5 \mathrm{~mm}$ in diameter as large colonies. Table 3 indicates the data in which the frequency of large colonies depended upon the inoculum dcse of HFV.

Table 3. Frequency of large colonies produced by the cells treated with HFV or iHFV or HNSL

\begin{tabular}{|c|c|c|c|c|c|c|c|}
\hline \multirow{2}{*}{$\begin{array}{l}\text { Virus } \\
\text { Source }\end{array}$} & \multirow{2}{*}{$\begin{array}{l}\text { Treatment } \\
\text { with }\end{array}$} & \multirow{2}{*}{$\begin{array}{l}\text { Single** } \\
\text { cell } \\
\text { rate }(\%)\end{array}$} & \multicolumn{5}{|c|}{ Frequency of large colonies } \\
\hline & & & \multicolumn{2}{|c|}{$\begin{array}{c}\text { per } 10^{4} \text { cells seeded } \\
\text { Mean }\end{array}$} & \multicolumn{3}{|c|}{$\begin{array}{c}\text { per } 10^{3} \text { cells seeded } \\
\text { Mean }\end{array}$} \\
\hline \multirow{3}{*}{ Dr. Oboshi } & untreated & 85 & 8 & 7 & 0 , & 0 & 0 \\
\hline & $0.05 \mathrm{ml} \mathrm{HFV}$ & 80 & 15,9 & 12 & 0 , & 0 & 0 \\
\hline & $0.05 \mathrm{ml} \mathrm{HFV}$ & 93 & $43, \quad 45$ & 44 & 1 , & 2 & 1.5 \\
\hline \multirow{3}{*}{ Dr. Odaka } & untreated & 96 & innumerabl & & 2 , & 3 & 2.5 \\
\hline & $0.05 \mathrm{ml} \mathrm{HFV}$ & 98 & innumerabl & & 5 , & 3 & 4 \\
\hline & $0.50 \mathrm{ml} \mathrm{HFV}$ & 96 & innumerab & & 13 , & 11 & 12 \\
\hline \multirow{4}{*}{ Dr. Oboshi } & untreated* & 89 & not done & & 3 & & 3 \\
\hline & $0.01 \mathrm{ml} \mathrm{HFV}$ & 81 & not done & & & 6 & 7.5 \\
\hline & $0.10 \mathrm{ml} \mathrm{HFV}$ & 84 & not done & & 30 , & & 28 \\
\hline & $0.10 \mathrm{ml} \mathrm{iHFV}$ & 92 & not done & & 4 & 3 & 3.5 \\
\hline \multirow{3}{*}{ Dr. Oboshi } & untreated & 97 & 0 & 0 & & 0 & 0 \\
\hline & $0.40 \mathrm{ml} \mathrm{HNSL}$ & 91 & 0 & 0 & 0 , & 0 & 0 \\
\hline & $0.40 \mathrm{ml} \mathrm{HFV}$ & 91 & $17, \quad 12$ & 14.5 & & 2 & 2.5 \\
\hline
\end{tabular}

* The infection was performed in tubes containing the cells in an amount of $1 \times 10^{5}$ cells per tube.

** Single cell rate at the time of plating the treated or untreated cells.

The cells treated with HFV grew more rapidly than the untreated cells (Fig. 1). Growth rate was dependent upon the inoculum dose of HFV (Fig. 2). No increase in the growth potential was observed with the cells treated with heat-inactivated HFV (iHFV), even though $\mathrm{iHFV}$ increased the density of cell population in the first monolayer culture (Fig. 3).

\section{Visus Assay in Vivo}

One of the HFV-treated cell lines (MLg42FV131) was assayed in vivo. At the indicated times recorded in Table 4, the final culture (medium + cells) or supernatant of culture medium centrifuged at 3,000 rpm for 30 minutes was taken from 7 day-old culture. Two-tenths $\mathrm{ml}$ of the sample were inoculated intraperitoneally into newborn ddY mice. They were observed for 2 months. When the undiluted culture medium was injected intraperitoneally into newborn $\mathrm{ddY}$ mice, the spleens of all the mice became palpable 


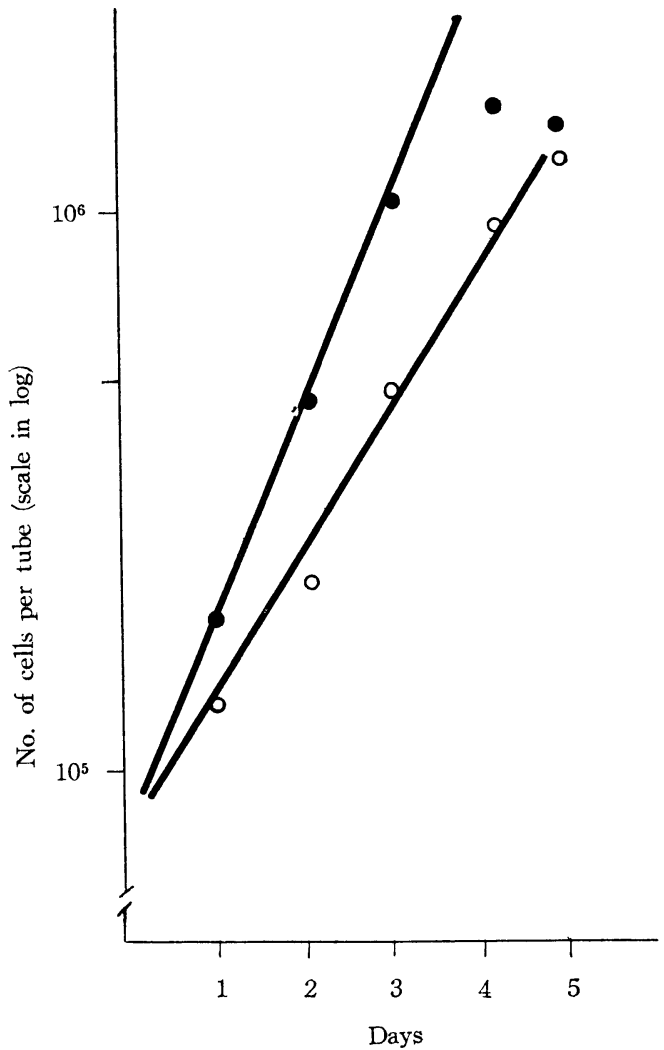

Fig. 1. The growth curve of the cells treated with HFV and that of the nontreated cells $(O)$. The virus was obtained from Dr. Oboshi.

within 3 weeks. The virus titer of the culture medium was higher than $\left.10^{3} \mathrm{ID}_{50} / 0.2 \mathrm{ml}\right]$ (Table 4). Spleens weighing $0.5 \mathrm{~g}$ or more were judged as an indication of infection. Pathological examinations of the mice injected with the samples from the infected cell lines revealed the typical Friend disease.

\section{DisCUSSION}

One of the characteristics of the cells transformed in vitro by tumor viruses, such as Rous sarcoma virus (RSV), is their rapid growth (Temin, 1965). The Friend leukemia? virus, one of the murine leukemia viruses, was found to increase the growth potential of the infected cells in the present investigation. This is in good accordance with the previous findings on Rous sarcoma virus.

Our experiments demonstrated that the treatment with homogenate of the Friend leukemia virus infected spleen (HFV) or heat-inactivated HFV (iHFV) increased the density of the cell population in the first monolayer culture, while homogenate of the noninfected spleens (HNS) or mixed homogenates of the noninfected spleens and livers (HNSL) did not. Furthermore, it was found with the subculture of the cells that only the cells treated with 


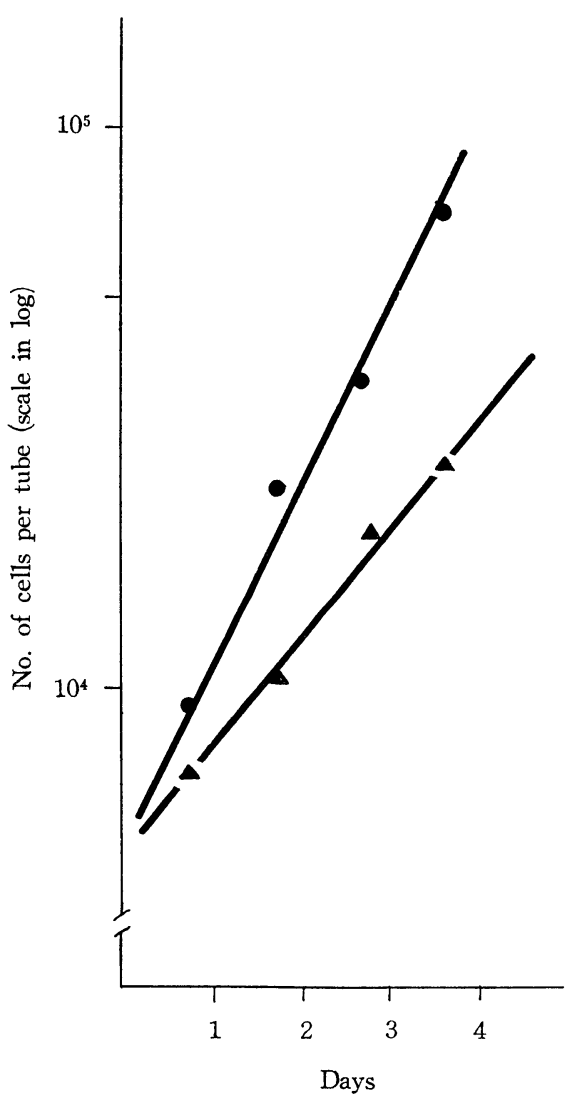

Fig. 2. The growth curve of the cells treated with $0.50 \mathrm{ml}$ of $\mathrm{HFV}$ (-) and that of the cells treated with $0.05 \mathrm{ml}$ of $\mathrm{HFV}(\boldsymbol{\Delta})$. The virus was obtained from Dr. Odaka.

$\mathrm{HFV}$, and not those treated with iHFV, were increased in the growth rate and formed large colonies (the increase in the growth potential): the increase in the growth potential was specifically induced by HFV and not by iHFV. These phenomena are summarized in Table 5.

These facts suggest that the infection with the Friend leukemia virus increased the growth potential of the infected cells, which was possibly mediated by some heat stable substance contained in both HFV and iHFV. In other words, when the Friend leukemia virus infects the cells in vivo or in vitro, the cells may begin to produce some heat-stable substance possibly promoting the cellular growth and inducing the loss of contact inhibition of the cells.

Recently Rubin has found growth controling substances prcduced by the normal or RSV-infected chick fibroblasts (Rubin, 1966a, b). The chick fibroblasts transformed by RSV grew poorly when spread on the glass surface unless the majority of the cell population was normal cells, but when suspended in soft agar, the transformed cells grew to a greater extent than the normal cells. During the investigation on the cause of these phenomena, he found that the normal chick fibroblasts produced two substances, 


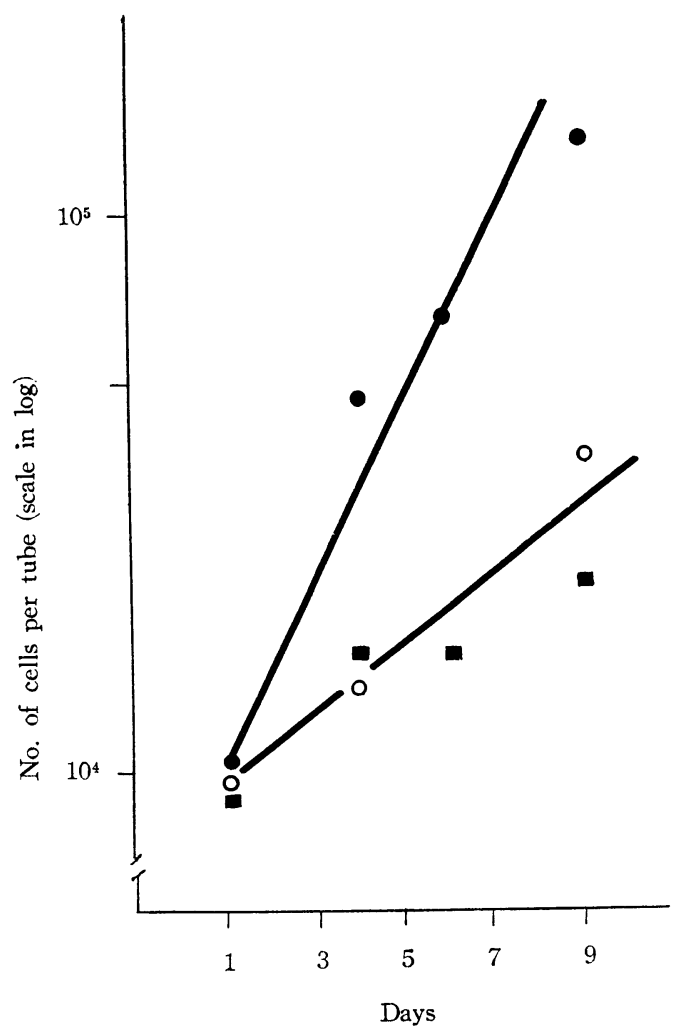

Fig. 3. The growth curve of the cells treated with $\mathrm{HFV}$ or with $\operatorname{iHFV}(\mathbf{)})$ or of the untreated cells $(\mathrm{O})$. The virus was obtained from Dr. Odaka.

one enhancing and the other inhibiting the growth of a small population of the normal cells. When transformed by RSV, the production of the growth inhibitory substance dominated. The growth enhancing substance was heat-labile and the inhibitory substance heat-stable. The phenomena observed by Rubin is different from those observed by us in Friend leukemia virus. But in the case of RSV, the transformed cells became round and probably difficult to grow after attaching to the glass surface, while the cells infected with Friend leukemia virus grew well on the glass surface.

Szent-Györgyi et al. (1962) isolated two substances from the thymus gland, one was promoting while the other inhibiting malignant growth, and they concluded that "the result depended on their balance". Similar growth promoting and inhibitory substances in normal or malignant tissues have been reported by many authors (Martinez et al., 1955 ; Miroff et al., 1955; Miroff 1964; Shear et al., 1951). According to Leaders et al. (1964) "these substances are members of a closely related family of nonspecific growth controling substances". The heat-stable substance contained in HFV or HFV which enhanced the growth of the cells in our experiments may be a member of nonspecific growth controling substances.

Normal cells may always be producing both growth promoting and growth inhibitory substances and the activities of both the substances may be in a state of equilibrium. 
Table 4. Viral assay in vivo (MLg42FV131)

\begin{tabular}{|c|c|c|c|c|c|c|}
\hline \multirow{3}{*}{$\begin{array}{l}\text { Days after } \\
\text { infection }\end{array}$} & \multirow{3}{*}{$\begin{array}{l}\text { Passage after } \\
\text { infection }\end{array}$} & \multirow{3}{*}{ Preparation } & \multirow{3}{*}{ Dilution } & \multicolumn{3}{|c|}{ Assay in vivo } \\
\hline & & & & \multicolumn{2}{|c|}{$\mathrm{L} / \mathrm{T}$} & \multirow{2}{*}{$\begin{array}{l}\text { Latent period* } \\
\text { (Days) }\end{array}$} \\
\hline & & & & No. & $\%$ & \\
\hline 35 & 2 & $\mathrm{~F}$ & undiluted & $7 / 7$ & 100 & $14-19$ \\
\hline 47 & 3 & $\mathrm{~F}$ & undiluted & $10 / 10$ & 100 & $16-17$ \\
\hline \multirow[t]{2}{*}{63} & 5 & M & undiluted & $6 / 6$ & 100 & $12-19$ \\
\hline & & & $10^{-1}$ & $7 / 7$ & 100 & $12-19$ \\
\hline \multirow[t]{4}{*}{70} & 5 & $\mathrm{M}$ & undiluted & $8 / 8$ & 100 & $15-21$ \\
\hline & & & $10^{-1}$ & $7 / 7$ & 100 & $20-23$ \\
\hline & & & $10^{-2}$ & $5 / 5$ & 100 & $20-24$ \\
\hline & & & $10^{-3}$ & $7 / 7$ & 100 & $35-61$ \\
\hline \multirow[t]{4}{*}{76} & 6 & $\mathrm{M}$ & undiluted & $9 / 9$ & 100 & $15-21$ \\
\hline & & & $10^{-1}$ & $7 / 7$ & 100 & $15-23$ \\
\hline & & & $10^{-2}$ & $6 / 6$ & 100 & $20-23$ \\
\hline & & & $10^{-3}$ & $7 / 7$ & 100 & $20-39$ \\
\hline \multirow[t]{4}{*}{90} & 8 & M & undiluted & $6 / 6$ & 100 & $13-23$ \\
\hline & & & $10^{-1}$ & $6 / 7$ & 86 & $13-61$ \\
\hline & & & $10^{-2}$ & $3 / 6$ & 50 & $34-41$ \\
\hline & & & $10^{-3}$ & $2 / 6$ & 33 & 41 \\
\hline
\end{tabular}

$\mathrm{F}=$ final culture. $\mathrm{M}=$ culture medium. $\mathrm{L} / \mathrm{T}=$ leukemia mice/total mice.

* days elapsing between the inoculation and appearance of the palpable spleens.

Table 5. Action of HFV, iHFV or HNSL on the MLg cells

\begin{tabular}{ccc}
\hline \multirow{2}{*}{ Treatment with } & \multicolumn{2}{c}{ Effect of the preparations } \\
\cline { 2 - 3 } & $\begin{array}{c}\text { Increase in the density of the } \\
\text { cell population in the } \\
\text { first monolayer culture }\end{array}$ & $\begin{array}{c}\text { Increase in the growth } \\
\text { potential of the cells }\end{array}$ \\
\hline HFV & + & + \\
heat-inactivated HFV & + & - \\
HNS or HNSL & - & - \\
\hline
\end{tabular}

When a tumor virus, such as Friend leukemia virus, infects the cell, the production of the growth promoting substance may dominate in the infected cell, resulting in a rapid growth of the infected cell.

The reason why rapidly growing cells appeared focally even with heat-inactivated HFV is not yet clear. It was not due to the cell aggregation in the area, because the population of dead cells around the area remained almost constant from the beginning of the treatment. Even in the untreated cultures, we found areas where the cells were slightly more crowded than the other part, but the cells still remained in a monolayer. The rapidly growing cells in the treated cultures showed multilayered pattern which was easily 
distinguished from that in the untreated ones.

The conditions required for demonstrating the increased growth potential of the cells treated with HFV are not yet well established. The increase in the growth potential, as well as the growth acceleration in the first monolayer culture, seemed to occur in some special conditions. We previously reported that the passage of the cells at the time of the infection was one of the important prerequisites (Yoshikura et al. 1965) when MLg cells at the 30th, 60th and 87th passages were inoculated with the same virus preparation, only the growth of the cells at the 60th passage were increased in the growth potential. We recently found that MLg cells at the 31st passage at the time of infection (MLg31FV137) produced the virus very well after treatment with HFV. The growth potential was not increased in this case. The increase in the growth potential was, therefore, not always associated with the establishment of the persistently infected cell lines. We have an impression that the high virus titer, $10^{4} \mathrm{ID}_{50} / 0.25 \mathrm{ml}$ or higher of the inoculum was also necessary for demonstrating the increased growth potential.

The data concerning the properties of the persistently infected cell lines, including bioassay data and observations with electronmicroscopy, will be detailed elsewhere.

\section{REFERENCES}

Chamorro, A., Latarjet, R., Vigier, P. And Zajdela, F. (1962): New investigations on the Friend disease. In Ciba Found. Symp. Tumor Viruses of Murine Origin. Boston, Little, Brown \& Co., pp 176-184.

GiNSBURG, H. AND SACHS, L. (1961) : In vitro culture of a mammalian leukemia virus. Virology $13,380-382$.

LEADERS, F. E., WERDER, A. A. AND SCHMIDT, C. (1964) : Erythropoietic stimulating factor (ESF) as a stimulant of cell growth in vitro. Proc. Soc. Exptl. Biol. Med. 115, 658-660.

Manaker, R. A., Strother, P. C., Miller, A. A. And Piczak, C. V. (1960) : Behavior in vitro of a mouse lymphoid-leukemia virus. J. Natl. Cancer Inst. 25, 1411-1419.

Manaker, R. A., Jensen, E. M. AND Korol, W. (1964) : Long-term propagation of a murine leukemia virus in an established cell line. J. Natl. Cancer Inst. 33, 363-371.

Martinez, C., Miroff, G. ANd Bittner, J. J. (1955): Studies on the heat-stable accelerant from transplanted and spontaneous mammary tumors in mice. Cancer Res. 15, 442-444.

Miroff, G., Martinez, C. ANd BitTNeR, J. J. (1955): Acceleration in the transplantation and killing time of mammary tumors in mice pretreated with a heat stable tumor tissue preparation. Cancer Res. 15, 437-441.

Miroff, G. (1964): Cellular metabolic alterations produced by the mammary tumor agent. Proc. Am. Ass. Cancer Res. 5, 179.

MoORE, A. E. AND FrIEND, C. (1958): Attempts at growing the mouse leukemia virus in tissue culture. Proc. Am. Ass. Cancer. Res. 2, 328.

MOORE, A. E. (1963) : Growth and persistence of Friend leukemia virus in tissue culture. J. Natl. Cancer Inst. 30, 885-895.

Moskowitz, M. AND SCHENCK, D. M. (1965): Growth promoting activity for mammarian cells in fractions of tissue extracts. Exptl. Cell. Res. 38,523-535.

Osato, T., Mirand, E. A. AND Grace, J. T., Jr. (1964) : Propagation and immunofluorescent investigations of Friend virus in tissue culture. Nature (London) 201, 52-54.

Osato, T., Mirand, E. A., Grace, J. T., Jr. ANd Price, F. (1966): In vitro malignant transformation of cells by Friend virus. Nature (London) 209, 779-782.

Peries, J., Levy, J. P., Bolron, M. ANd Bernard, J. (1964) : Multiplication of Rauscher virus in cultures of mouse kidney cells. Nature (London) 203, 672.

Rubin, H. (1966a): A substance in conditioned medium which enhances the growth of small numbers of chick embryo cells. Exptl. Cell. Res. 41, 138-148. 
RuBIN, H. (1666b) : The inhibition of chick embryo cell growth by medium obtained from cultures of Rous sarcoma cells. Exptl. Cell. Res. 41, 149-161.

Shear, H. H., Imagawas, D. T. AND Syverton, J. T. (1951) : Presence in tumor tissue of a mouse mammary cancer accelerant. Proc. Soc. Exptl. Biol. Med. 78, 281.

Sinkovics, J. G. AND HowE, C. D. (1964) : Growth characteristics, virus yield and interferon assay of leukemia mouse spleen tissue cultures. J. Infect. Dis. 114, 359-372.

Szent-GyÖRgYI, A., HegYell, A. AND McLAughlin, J. A. (1962): Constituents of the thymus gland and their relation to growth, fertility, muscle and cancer. Proc. Natl. Acad. Sci. USA 48, 1439-1442.

TAKano, K., Yamada, M. AND Yaginuma, K. (1956): Growth estimation of HeLa strain cells in tissue culture by nucleus emuneration method. Japan. J. Med. Sci. Biol. 9, 17-26.

TEMIN, H. M. (1965) : The mechanism of carcinogenesis by avian sarcoma viruses. Cell multiplication and differentiation. J. Natl. Cancer Inst. 35, 679-693.

WRIGHT, B. S. AND LASFARGUES, J. C. (1965) : Long-term propagation of the Rauscher murine leukemia virus in tissue culture. J. Natl,. Cancer Inst. 35, 319-327.

Yoshikura, H., Hirokawa, Y. AND Yamada, M. (1965): Growth acceleration of a mouse cell strain after treatment with homogenate of the Friend virus infected spleen: A preliminary report. Japan. J. Med. Sci. Biol. 18, 261-266 